Hypothesis

\title{
Extending UTAUT Theory to Compare South Korean and Chinese Institutional Investors' Investment Decision Behavior in Cambodia: A Risk and Asset Model
}

\author{
Wei Sun ${ }^{1, *}$, Alisher Tohirovich Dedahanov ${ }^{2} \mathbb{C}$, Ho Young Shin ${ }^{2}$ and Ki Su Kim ${ }^{2}$ \\ 1 School of Economic, Anyang Normal University, Anyang 455001, China \\ 2 School of Business, Yeungnam University, Gyeongsan-si 38541, Korea; sarbon22513@ynu.ac.kr (A.T.D.); \\ ho-ing@nate.com (H.Y.S.); kskim@yu.ac.kr (K.S.K.) \\ * Correspondence: popupoler@tom.com; Tel.: +86-176-0372-0269
}

Received: 5 December 2019; Accepted: 13 December 2019; Published: 16 December 2019

\begin{abstract}
This study is designed to provide strategic inspiration in multinational institutions' investment behavior in Cambodia. Most factors affecting the investment decisions of South Korean and Chinese institutional investors in Cambodia are investigated based on UTAUT theory. Perceived asset price and perceived asset quality proves to have a significant effect on perceived asset value, whereas perceived financial risk proves to have a significant negative effect on the relationship between perceived asset value and investment decision for the Chinese group, but not for the South Korean group. Facilitating conditions proves to have an important effect in investment decisions for the South Korean group, but not for the Chinese group. Furthermore, perceived asset value, social influence and performance expectancy prove to have a significant effect on investment decisions for both groups. Although both South Korean and Chinese institutional investors are plentiful in Cambodia, the investigation indicates that they maintain symmetry in investment competition due to their different preferences in investment objects and types. The results reinforce major implications in offering a more symmetrical and fair competition environment for both Cambodian regulators and multinational institutions.
\end{abstract}

Keywords: comparative study; symmetrical competition; UTAUT; investment; perceived financial risk; South Korea; China; Cambodia

\section{Introduction}

In the past two decades a significant development in multinational international investment business has been the rise of investment in emerging markets, such as Cambodia. Foreign investment is to profit from future return in compensation for the cost of forgoing present consumption [1]. Foreign capital is like a vehicle to help Cambodia access the newest economic opportunities, and offering her more skills for future growth. Given the investment behavior in emerging markets, institutional investors pursue multiple investments with different types of alternative assets, forming a portfolio [2]. Under a multinational corporation view of investment, plenty of the literature has addressed different factors affecting investment behavior in international investment situations [3-8]. However, only some research has yet to compare and address the investment characteristics from different countries in Cambodia to explain how South Korean and Chinese institutional investors can maintain symmetry in investment competition and keep harmony. The significance of focusing on important factors from different countries in the area of investment in Cambodia to achieve a better understanding of institutional decision behavior is useful for both applied and strategic grounds in attracting foreign 
investment. Thus, discussing factors affecting institutional investors from different countries can effectively develop and manage investment field in Cambodia and is necessary and important for further investigation.

This research investigates both the indirect and direct effects of the determinations on South Korean and Chinese institutional investors' investment decisions using an extending and integrated model, attempting to find earlier international investment studies, and retrieving the determinants of investment decision in Cambodia. As more and more papers about the business of international investment appear, different models are applied to test investment behavior in different situations. This research has undertaken the unified theory of acceptance and use of technology models and has expanded it by new mediating and moderating variables.

As international investment in the least-developed countries involves potential financial risk that is important and difficult to find, and risk concerns may be a barrier to investment decisions in Cambodia, therefore perceived financial risk is necessary in our model to offer better comprehension of risk factors that could explain South Korean and Chinese institutional investors' actual institutional investment behavior in Cambodia. At the same time, a component of perceived asset value is also contained to compare and estimate the success of South Korean and Chinese institutional investors' investment decisions within Cambodian assets' quality and price, filling in a blank of research in this academic area of great financial and economic interests.

This study is planned to compare South Korean and Chinese institutional investors' investment decision behaviors in Cambodia. The behavioral factors used for comparison are the following: (1) perceived asset quality, (2) perceived asset price, (3) perceived asset value, (4) perceived financial risk, (5) facilitation condition, (6) social influence, and (7) performance expectancy. The study hopes to not only offer practical implications that can help the institutional investors from different countries retrieve the relative institutional investors' decision behavior on investment in Cambodia, but also provide a reference for the Cambodian government to attract more foreign investment by offering a more symmetrical and fair competition environment.

\section{Theoretical Background}

\subsection{Prior Research on Transnational Investment Behavior}

The business of transnational investment has received colossal attention in recent years. Verbeke \& Kano [9] argue that adopting the best-matched resource recombination practices will advance many multinational enterprises' success outside of its home region. Hitt, Li \& Xu [10] examine multinational enterprises' international strategy and highlight emerging research themes, such as institutional complexity, business sustainability, emerging economy firms, and international new ventures. Casson \& Wadeson [11] explain emerging-market multinationals in terms of internalization theory. $\mathrm{Wu}, \mathrm{Ma} \&$ Zhuo [12] find that both high-tech-related international export and inward foreign direct investment significantly contribute to emerging countries' ability to produce cutting-edge technologies. Chen et al. [13] investigate the link between the characteristics of a foreign investment opportunity and firm management and find that institutional environment matters to the firm's financial behavior. Julio \& Yook [14] investigate several potential explanations and find evidence supporting the idea that political uncertainty leads institutional investors to reduce investment expenditures. Walter \& Sisli [15] examine the development of transnational asset management of financial markets among Asian developing economies, including China, Philippines, Indonesia, Singapore, South Korea, Thailand and Malaysia, and indicate that Asian asset management industry will keep growing, products of asset management will increase and Asian financial market will be significantly affected by transnational asset management. The previous research has shown how necessary it is to better understand the determinants of transnational investors' investment decisions, especially in the circumstance of Cambodia. 


\subsection{Prior Research on Investment Behavior in Cambodia}

As one of the least developed countries, Cambodia remains a valuable emerging market for all potential investors across the world. Several previous pieces of research have focused on investment behavior in Cambodia. Foreign investment in Cambodia inflows are seen as one method of boosting economic development and growth, and assisting in the transition process-consisting of both economic reforms and business liberalization measures-underway in the country. Sokang [16] investigates the impact of foreign direct investment inflows on the economic growth of Cambodia and recommends that the government should bring reform in the domestic market to attract more foreign direct investment in Cambodia. Wittwer et al. [17] and Zeug et al. [18] investigate the gems in Ratanakiri Province, North-Eastern Cambodia and prove the gems are still modestly priced and also come with collecting and investment potential. Aiba et al. [19] investigates the determinants of foreign currency borrowing of households in Cambodia based on the condition of the Cambodian financial dollarization situation and give investment suggestions about management of risk-hedging behavior against exchange rate risks for Cambodian households. Samreth [20] examines whether the currency substitution phenomenon in Cambodia is in a hysteresis state and recommends related investment suggestions. Multinational investment not only plays a significant role in economic growth but is also an important method to introduce modernized finance, technology and management knowledge into Cambodia. The previous research has also shown the importance to better understand the behavior of transnational investors' investment decisions in Cambodia.

\subsection{Extended Unified Theory of Acceptance and Use of Technology (UTAUT2)}

After Venkatesh et al. [21] developed the unified theory of acceptance and use of technology (UTAUT), several previous studies have continuously tried to apply UTAUT into different areas to explain different behaviors, as well as in organizational or institutional contexts. Although Venkatesh et al. [21] proposed age, gender, experience and voluntariness of use as moderators, quite a few researchers have replaced them by other variables or not applied them in their researches [22,23]. This research modifies UTAUT2 by comprising institutional factors and replacing an old moderator with perceived financial risk. The following describes and discusses constructions within the modified model based on the institutional investment situations of Cambodia.

\section{Hypotheses and Research Model}

\subsection{Perceived Asset Value and Perceived Asset Quality}

Perceived asset quality is defined as investors' actual expectations of assessment of Cambodian assets' performance, because perceived quality has been widely studied [24-26]. Perceived quality's positive relationship with perceived value has been tested in both the marketing and finance literature $[27,28]$. Therefore, this study assumes that the quality of assets will be carefully evaluated by institutional investors by consulting the Cambodian investment situations and asset holders before deciding whether or not to invest in certain kinds of assets. From this perspective, as a higher level of asset quality is perceived, a higher value could be accepted by investors. Thus, perceived asset quality may have a positive effect on perceived asset value. Therefore, the hypothesis is proposed as follows:

Hypothesis 1. The perceived asset quality has a positive effect on the perceived asset value.

\subsection{Perceived Asset Value and Perceived Asset Price}

Perceived asset price is defined as investors tending to perceive prices in an expectation of future prices increasing in a way that is meaningful to them, rather than the current actual price. Perceived asset prices could be more attractive to investors than actual prices because different prices show different signals and opportunities for different institutional investors in the future. Since institutional investors always analyze the assets and then create the most attractive asset package of safety and 
appreciation potential, the components of perceived asset price not only contain current monetary price, but also expected future price hikes. Accordingly, institutional investors are intent on being equitably treated when the ratio of their outcome to inputs is equal to the outcome [25,27]. From this perspective, after a higher level of expected future asset price is perceived, a higher asset value will be automatically perceived. Thus, perceived asset price may have a positive effect on perceived asset value. Therefore, the hypothesis is as follows:

Hypothesis 2. The perceived asset price has a positive effect on the perceived asset value.

\subsection{Perceived Asset Value and Investment Decision}

Perceived asset value is defined as the quality, benefits and utility that institutional investors receive and the sacrifices in using the assets $[24,29,30]$. Similarly, when the perceived value of assets outstrips costs, it is more likely for investors to make an investment decision. Accordingly, quite a few previous pieces of research have proved that perceived value has a positive effect on behaviors in different contexts [24,31]. Therefore, if institutional investors can perceive a higher value for assets of Cambodian markets than for most other markets, they will be more intent to invest in Cambodia. Thus, the hypothesis is proposed:

Hypothesis 3. The perceived asset value has a positive effect on investment decision.

\subsection{Perceived Financial Risk Moderating Effect between Perceived Asset Value and Investment Decision}

Dowling \& Staelin [32] indicate that risk is the perception of the uncertainty and adverse consequences of engaging in an activity, whereas financial risk is potential monetary loss or perception of insecurity $[33,34])$. Financial risk is considered as the most influential factor in the process of making finance-related decisions [33-37]. Therefore, in this work, perceived financial risk is defined as institutional investors' consideration about how investment decisions bring perception of insecurity or potential monetary loss. On the one hand, institutional investors may consider Cambodian financial markets' investment behaviors take action to make profits. On the other hand, they will feel dangerous because of perceived financial risk in the investment process. Although institutional investors may invest in Cambodian markets due to the value of the assets, they may change their ideas due to the perceived financial risk in their investment. Some of the literature has proven that people's financial behaviors with higher risks will lead to less behavior decisions [33,37]. The cause of the situation in this case might be that institutional investors care more about the long-term investment environment than benefits [38]. In foreign investment behavior, institutional investment managers often go through the whole decision process and take into account a comprehensive consideration of various factors (e.g., future potential price, taxes, processing fees, service charge, exchange rate and delivery costs) before the final decision. Institutional investors may not decide to invest even if the assets are valuable when they perceive high financial risk. Therefore, the hypothesis is:

Hypothesis 4. Perceived financial risk has a negative moderating effect on the relationship between perceived value and investment decision.

\subsection{Facilitating Conditions and Investment Decision}

Facilitating conditions represent the conceptualized knowledge, resources and opportunities to perform a specific behavior and refers to perceptions of the resources and support available to perform a behavior [39]. This research assumes that facilitating conditions may help institutional investors by providing knowledge, resources, and help to make a decision on investment in Cambodia. Plenty of research has shown facilitating conditions to be significant to specific behaviors or reasons for investment [23,40-43]. In the process of investment behavior, the lack of financial data infrastructure, fast internet connectivity, appropriate financial software or information systems, etc., could be a barrier 
to making proper investment behaviors. Furthermore, the absence of support from governments, NGOs and institutional colleagues could make it even tougher in Cambodia. Therefore, the proposed hypothesis is:

Hypothesis 5. Facilitating conditions has a positive effect on investment decision.

\subsection{Social Influence and Investment Decision}

Venkatesh et al. [39] indicate that social influence is the degree to which consumers perceive that important others (e.g., family and friends) believe they should use a particular technology. In this research, social influence is defined as the extent to which institutional investors perceive that important others (e.g., other institutional peer colleagues or competitors) believe they should be intent to invest in Cambodia. In terms of investment in Cambodia, social influence means social pressure on institutional investors to find assets of high capital gain potential to exceed in business competition. Thus, social influence is assumed to have a positive effect on institutional investors' investment decision. Therefore, it is hypothesized as:

Hypothesis 6. Social influence has a positive effect on investment decision.

\subsection{Performance Expectancy and Investment Decision}

Performance expectancy is the extent to which using a technology will provide benefits to consumers in performing certain activities [39]. In this work, performance expectancy is defined as the degree to which investing in Cambodian markets will provide benefits both to institutions and institutional investor managers themselves. Institutional investors are more apt to invest in Cambodia markets when they perceive that investment would help them to make more profits. Thus, drawing on UTAUT2, it is hypothesized as:

Hypothesis 7. Performance expectancy has a positive effect on investment decision.

Figure 1 shows the proposed research model.

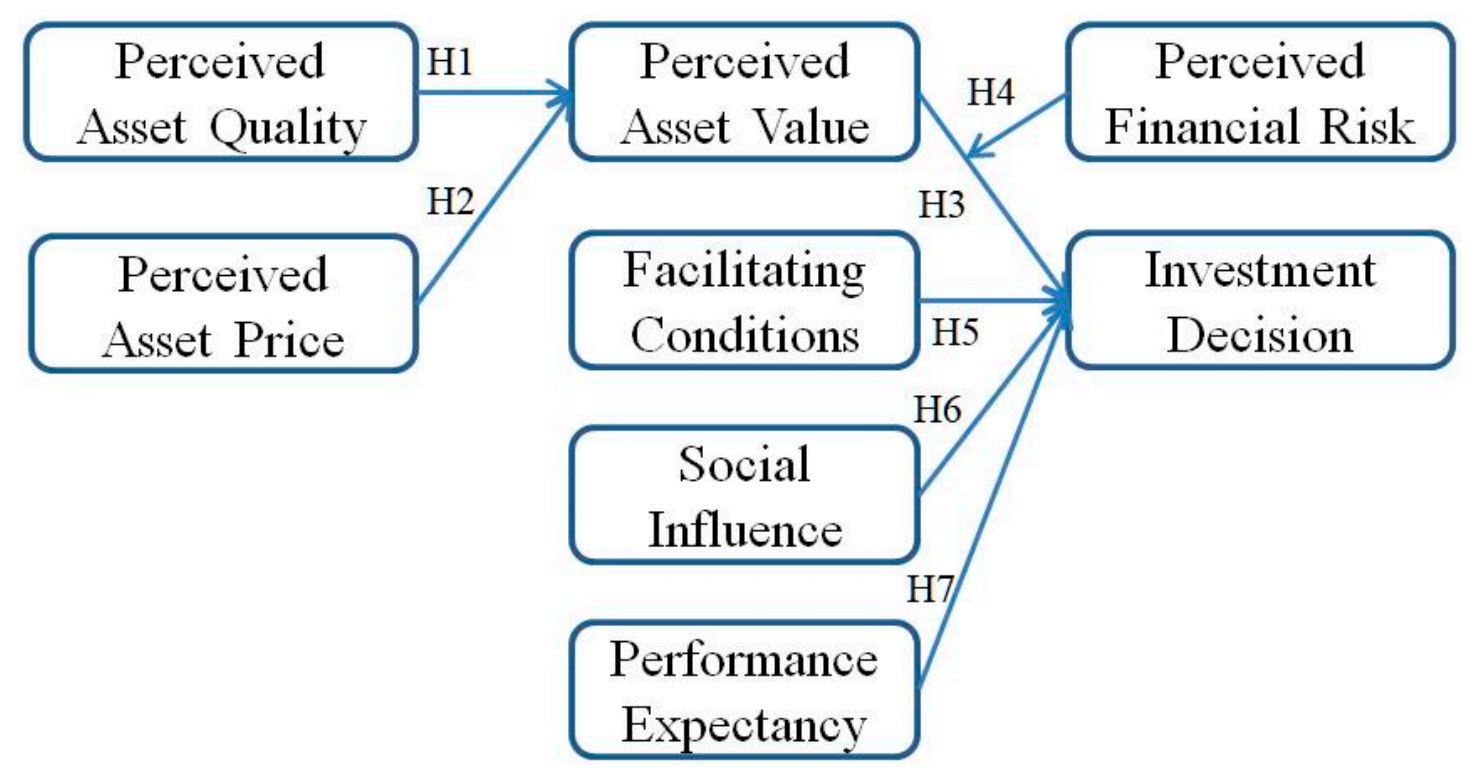

Figure 1. The proposed research model. 


\section{Methodology, Measurement and Analysis}

It was necessary to survey multinational companies' investment managers that have implemented investment or are quite familiar with Cambodian investment markets. RHB (Rashid Hussein Bank) group is the fourth largest financial group in Malaysia. The multinational investment companies were randomly selected to serve in this study for some reasons as follows: 1) Most of them have stayed in Cambodia for years and are full of relevant experience in investment tasks; 2) all of them have business with RHB banks, which prove that they have launched substantial investment works; 3) because their investment work covers various fields, the deviation of investment scope is avoided; 4) the shareholders of RHB bank are neither Chinese nor Korean, which ensures the neutrality and randomness of sampling respondents. This study also included a pretest $(N=32)$ to confirm the validity and reliability of the final survey. The pretest respondents were asked to give advice to improve the quality of the survey overall, and the final survey questionnaire was updated according to their suggestions.

With the help of Cambodian RHB Securities, we collected data from 37 multinational investment companies in Phnom Penh, each through a contact person who worked in a managerial position. The contact person of each multinational investment company randomly selected 5-25 investment managers and contacted them by phone. They were invited to complete an online survey. Respondents were offered two movie coupons as prizes. A total of 216 responses were received in two weeks. The response rate was 39\%. The measurement is showed in Table 1. A 7-point Likert scale test was applied in the survey, where 1 is strongly disagree and 7 is strongly agree.

Table 1. Variables and measurements.

\begin{tabular}{|c|c|}
\hline Variable & Measurement \\
\hline $\begin{array}{l}\text { Perceived asset } \\
\text { quality [24] }\end{array}$ & $\begin{array}{l}\text { 1. Assets of Cambodia are financially appealing. } \\
\text { 2. Assets of Cambodia make it easy for investors to find what they need. } \\
\text { 3. Quality of assets in Cambodia is relatively high. }\end{array}$ \\
\hline $\begin{array}{l}\text { Perceived asset } \\
\text { price [24] }\end{array}$ & $\begin{array}{l}\text { 1. The current price of assets in Cambodia is reasonable. } \\
\text { 2. The current price of assets in Cambodia is inexpensive. } \\
\text { 3. I would be pleased to invest in assets of Cambodia at the current price. }\end{array}$ \\
\hline $\begin{array}{c}\text { Perceived asset } \\
\text { value [23] }\end{array}$ & $\begin{array}{l}\text { 1. I consider the present assets in Cambodia to be good value. } \\
\text { 2. Present assets in Cambodia have a good level of investment potential. } \\
\text { 3. Present assets in Cambodia appear to be beneficial to me. }\end{array}$ \\
\hline $\begin{array}{c}\text { Perceived } \\
\text { financial risk ([44] }\end{array}$ & $\begin{array}{l}\text { 1. There is a chance that I will lose money because of the high cost to maintain assets in } \\
\text { Cambodia. } \\
\text { 2. Investing in Cambodia is risky in terms of long-term costs. } \\
\text { 3. Investing in Cambodia will lead to a loss of money because of spending a lot of time } \\
\text { and effort to sell them out. }\end{array}$ \\
\hline $\begin{array}{c}\text { Facilitating } \\
\text { conditions [41] }\end{array}$ & $\begin{array}{l}\text { 1. I have the resources necessary to invest in the assets of Cambodia. } \\
\text { 2. I have the knowledge necessary to invest in the assets of Cambodia. } \\
\text { 3. Investing in Cambodia is compatible with other financial systems I use. }\end{array}$ \\
\hline $\begin{array}{l}\text { Social influence } \\
\qquad[41]\end{array}$ & $\begin{array}{l}\text { 1. People who influence my behavior think that I should invest in the assets of Cambodia. } \\
\text { 2. People who are important to me think that I should invest in the assets of Cambodia. } \\
\text { 3. People whose opinions that I value prefer that I should invest in the assets of } \\
\text { Cambodia. }\end{array}$ \\
\hline $\begin{array}{c}\text { Performance } \\
\text { expectancy [41] }\end{array}$ & $\begin{array}{l}\text { 1. I think that investing in the assets of Cambodia would enable me to make profits more } \\
\text { quickly. } \\
\text { 2. I think that investing in the assets of Cambodia would increase my productivity. } \\
\text { 3. I think that investing in the assets of Cambodia would improve my performance. }\end{array}$ \\
\hline $\begin{array}{l}\text { Investment } \\
\text { decision [45] }\end{array}$ & $\begin{array}{l}\text { 1. I am likely to invest in the assets of Cambodia. } \\
\text { 2. I desire to invest in the assets of Cambodia. } \\
\text { 3. I plan to invest in the assets of Cambodia. }\end{array}$ \\
\hline
\end{tabular}




\subsection{Data Analysis}

Smart PLS 3.0 was applied to test the validity and reliability of the research model as well as analyzing the structural model including significance of path coefficients, path coefficients and explained variance of endogenous constructs. Bootstrap t-statistics in this study is 5000 resamples.

\subsection{Data Gathering}

It was possible to gather a lot of South Korean and Chinese investment institutions' contact information with the help of the Ministry of Commerce of Cambodia. A total of 172 valid South Korean respondents and 253 valid Chinese respondents were surveyed online from 21 August to 5 September 2018. The results indicate that there are relatively high differences in the categories of education level, working years and fund size. Notably, it also shows the South Korean and Chinese groups hold quite different preferences in investment objects and types. A total of $61.1 \%$ of Chinese institutional investors focus on real estate and the entertainment industry, whereas only $28.8 \%$ of South Korean institutional investors focus on these areas. Most Chinese institutional investors are rarely interested in manufacturing and the financial industry, whereas 33\% of South Korean institutional investors focus on these areas. The descriptive statistics on respondents' demographic and other useful data were summarized in Table 2.

Table 2. Distribution of survey respondents.

\begin{tabular}{|c|c|c|c|c|c|}
\hline \multirow{2}{*}{ Category } & \multirow{2}{*}{ Subject } & \multicolumn{2}{|c|}{ South Korea } & \multicolumn{2}{|c|}{ China } \\
\hline & & $N$ & $\%$ & $N$ & $\%$ \\
\hline \multirow{4}{*}{ Education Level } & High school & 12 & $6.9 \%$ & 108 & $42.9 \%$ \\
\hline & Bachelor & 124 & $72.1 \%$ & 114 & $44.9 \%$ \\
\hline & Master & 30 & $17.5 \%$ & 28 & $11.0 \%$ \\
\hline & Ph.D & 6 & $3.5 \%$ & 3 & $1.2 \%$ \\
\hline \multirow{4}{*}{ Age } & $23-30$ & 24 & $14.5 \%$ & 81 & $32.3 \%$ \\
\hline & $30-40$ & 97 & $56.0 \%$ & 137 & $53.9 \%$ \\
\hline & $40-50$ & 36 & $20.8 \%$ & 29 & $11.4 \%$ \\
\hline & Over 50 & 15 & $8.7 \%$ & 6 & $2.4 \%$ \\
\hline \multirow{3}{*}{$\begin{array}{c}\text { Investment } \\
\text { Working Years in } \\
\text { Cambodia }\end{array}$} & $1-3$ years & 50 & $29.5 \%$ & 142 & $56.3 \%$ \\
\hline & $3-6$ years & 95 & $54.9 \%$ & 81 & $31.9 \%$ \\
\hline & Over 6 years & 27 & $15.6 \%$ & 30 & $11.8 \%$ \\
\hline \multirow{8}{*}{ Focus of Investment } & Real estate & 37 & $21.9 \%$ & 73 & $29.2 \%$ \\
\hline & Financial industry & 36 & $20.9 \%$ & 19 & $7.5 \%$ \\
\hline & Entertainment & 12 & $6.9 \%$ & 81 & $31.9 \%$ \\
\hline & Retail & 25 & $14.5 \%$ & 31 & $12.2 \%$ \\
\hline & Restaurant \& hotels & 16 & $9.2 \%$ & 18 & $7.1 \%$ \\
\hline & Mining & 15 & $8.7 \%$ & 19 & $7.5 \%$ \\
\hline & Manufacturing & 21 & $12.1 \%$ & 5 & $1.9 \%$ \\
\hline & Others & 10 & $5.8 \%$ & 7 & $2.7 \%$ \\
\hline \multirow{4}{*}{ Fund Size } & Under 10 million $\$$ & 104 & $60.7 \%$ & 148 & $58.6 \%$ \\
\hline & 10-20 million \$ & 39 & $22.5 \%$ & 82 & $32.3 \%$ \\
\hline & $20-50$ million $\$$ & 21 & $12.2 \%$ & 6 & $2.4 \%$ \\
\hline & Above 50 million $\$$ & 8 & $4.6 \%$ & 17 & $6.7 \%$ \\
\hline
\end{tabular}

\subsection{Descriptive Statistics}

Descriptive statistics for the study variables on the 7-point Likert scale are summarized in Table 3. The results indicate that there are relatively high differences on perceived financial risk and facilitating conditions between the South Korean and Chinese groups. 
Table 3. Descriptive statistics of latent variables.

\begin{tabular}{cccccc}
\hline \multirow{2}{*}{ Variables } & \multicolumn{2}{c}{ South Korea } & \multicolumn{2}{c}{ China } & \multirow{2}{*}{ Mean Gap } \\
\cline { 2 - 5 } & Mean & $\begin{array}{c}\text { Standard } \\
\text { Deviation }\end{array}$ & Mean & $\begin{array}{c}\text { Standard } \\
\text { Deviation }\end{array}$ & \\
\hline Perceived Asset Quality & 4.949 & 1.407 & 5.387 & 1.160 & -0.438 \\
\hline Perceived Asset Price & 4.917 & 1.221 & 4.885 & 1.244 & 0.032 \\
\hline Perceived Asset Value & 4.763 & 1.462 & 4.674 & 1.020 & 0.089 \\
\hline Perceived Financial Risk & 4.162 & 1.415 & 4.863 & 1.540 & -0.701 \\
\hline Facilitating Condition & 5.459 & 1.069 & 4.471 & 1.355 & -0.988 \\
\hline Social Influence & 4.707 & 1.205 & 4.894 & 1.162 & -0.187 \\
\hline Performance Expectancy & 4.380 & 1.365 & 4.553 & 1.235 & -0.173 \\
\hline Investment Decision & 4.878 & 1.247 & 5.135 & 1.464 & -0.257 \\
\hline
\end{tabular}

\subsection{Measurement Model}

Indicator reliability, internal consistency reliability, convergent validity and discriminant validity are examined when evaluating a research model process [46]. Table 4 indicates that composite reliability is suitable for PLS-SEM [47]. In our study the composite reliabilities range from 0.917 to 0.972 for the South Korean group and 0.908 to 0.956 for the Chinese group, which are above the 0.70 cut-off [48]. AVE (Average Variance Extracted) was also calculated for each constructs in our proposed model $[49,50]$. Results support convergent validity because all construct's AVE are above the 0.50 cut-off, which means the results support convergent validity. The Chinese group is in brackets and South Korea group is outside the brackets.

Table 4. Convergent validity and composite reliabilities testing results.

\begin{tabular}{|c|c|c|c|c|}
\hline Variables & Item & $\begin{array}{l}\text { Standardized } \\
\text { Loading }\end{array}$ & AVE & $\begin{array}{l}\text { Composite } \\
\text { Reliability }\end{array}$ \\
\hline \multirow{3}{*}{$\begin{array}{c}\text { Perceived Asset } \\
\text { Quality }\end{array}$} & PQ1 & $0.936(0.893)$ & \multirow{3}{*}{$0.915(0.908)$} & \multirow{3}{*}{$0.970(0.934)$} \\
\hline & PQ2 & $0.985(0.950)$ & & \\
\hline & PQ3 & $0.948(0.878)$ & & \\
\hline \multirow{3}{*}{$\begin{array}{c}\text { Perceived Asset } \\
\text { Price }\end{array}$} & PP1 & $0.934(0.933)$ & \multirow{3}{*}{$0.824(0.813)$} & \multirow{3}{*}{$0.933(0.941)$} \\
\hline & PP2 & $0.897(0.868)$ & & \\
\hline & PP3 & $0.890(0.924)$ & & \\
\hline \multirow{3}{*}{$\begin{array}{l}\text { Perceived Asset } \\
\text { Value }\end{array}$} & PV1 & $0.933(0.949)$ & \multirow{3}{*}{$0.889(0.875)$} & \multirow{3}{*}{$0.970(0.953)$} \\
\hline & PV2 & $0.969(0.973)$ & & \\
\hline & PV3 & $0.909(0.925)$ & & \\
\hline \multirow{3}{*}{$\begin{array}{c}\text { Perceived Financial } \\
\text { Risk }\end{array}$} & PR1 & $0.942(0.949)$ & \multirow{3}{*}{$0.877(0.894)$} & \multirow{3}{*}{$0.966(0.912)$} \\
\hline & PR2 & $0.924(0.976)$ & & \\
\hline & PR3 & $0.940(0.934)$ & & \\
\hline \multirow{3}{*}{$\begin{array}{l}\text { Facilitating } \\
\text { Condition }\end{array}$} & FC1 & $0.914(0.808)$ & \multirow{3}{*}{$0.839(0.812)$} & \multirow{3}{*}{$0.940(0.913)$} \\
\hline & FC2 & $0.919(0.919)$ & & \\
\hline & FC3 & $0.915(0.816)$ & & \\
\hline \multirow{3}{*}{ Social Influence } & SI1 & $0.934(0.876)$ & \multirow{3}{*}{$0.787(0.793)$} & \multirow{3}{*}{$0.917(0.908)$} \\
\hline & SI2 & $0.788(0.826)$ & & \\
\hline & SI3 & $0.932(0.912)$ & & \\
\hline \multirow{3}{*}{$\begin{array}{l}\text { Performance } \\
\text { Expectancy }\end{array}$} & PE1 & $0.970(0.951)$ & \multirow{3}{*}{$0.920(0.925)$} & \multirow{3}{*}{$0.972(0.941)$} \\
\hline & PE2 & $0.944(0.924)$ & & \\
\hline & PE3 & $0.963(0.968)$ & & \\
\hline \multirow{3}{*}{$\begin{array}{l}\text { Investment } \\
\text { Decision }\end{array}$} & II1 & $0.966(0.970)$ & \multirow{3}{*}{$0.917(0.929)$} & \multirow{3}{*}{$0.971(0.956)$} \\
\hline & II2 & $0.959(0.985)$ & & \\
\hline & II 3 & $0.949(0.941)$ & & \\
\hline
\end{tabular}


Discriminant validity is also considered. Table 5 shows that each construct's AVE's square root is higher than the correlations between it and any other construct in the research model. The diagonal is the square root of the AVE value and all constructs have more variance in their own blocks of indicators than with other latent variables. The Chinese group is in brackets and the South Korean group is outside the brackets.

Table 5. Descriptive statistics, correlation matrix and square roots of AVE.

\begin{tabular}{|c|c|c|c|c|c|c|c|c|}
\hline Construct & $P Q$ & PP & FC & PE & PV & SI & ID & PR \\
\hline$P Q$ & $\begin{array}{c}0.956 \\
(0.953)\end{array}$ & & & & & & & \\
\hline PP & $\begin{array}{c}0.256 \\
(0.232)\end{array}$ & $\begin{array}{c}0.907 \\
(0.902) \\
\end{array}$ & & & & & & \\
\hline FC & $\begin{array}{c}0.059 \\
(0.047)\end{array}$ & $\begin{array}{c}-0.048 \\
(-0.109)\end{array}$ & $\begin{array}{c}0.916 \\
(0.901)\end{array}$ & & & & & \\
\hline PE & $\begin{array}{c}0.171 \\
(0.193)\end{array}$ & $\begin{array}{c}-0.195 \\
(-0.145)\end{array}$ & $\begin{array}{c}0.264 \\
(0.217)\end{array}$ & $\begin{array}{c}0.959 \\
(0.961)\end{array}$ & & & & \\
\hline PV & $\begin{array}{c}0.462 \\
(0.477) \\
\end{array}$ & $\begin{array}{c}0.621 \\
(0.588) \\
\end{array}$ & $\begin{array}{c}-0.001 \\
(-0.043)\end{array}$ & $\begin{array}{c}-0.044 \\
(-0.029)\end{array}$ & $\begin{array}{c}0.943 \\
(0.935) \\
\end{array}$ & & & \\
\hline SI & $\begin{array}{c}0.387 \\
(0.399)\end{array}$ & $\begin{array}{c}0.159 \\
(0.193) \\
\end{array}$ & $\begin{array}{c}0.234 \\
(0.201) \\
\end{array}$ & $\begin{array}{c}0.346 \\
(0.308) \\
\end{array}$ & $\begin{array}{c}0.301 \\
(0.297)\end{array}$ & $\begin{array}{c}0.887 \\
(0.890)\end{array}$ & & \\
\hline ID & $\begin{array}{c}0.251 \\
(0.301) \\
\end{array}$ & $\begin{array}{c}0.032 \\
(0.085) \\
\end{array}$ & $\begin{array}{c}0.437 \\
(0.399) \\
\end{array}$ & $\begin{array}{c}0.668 \\
(0.567) \\
\end{array}$ & $\begin{array}{c}0.168 \\
(0.195) \\
\end{array}$ & $\begin{array}{c}0.555 \\
(0.507) \\
\end{array}$ & $\begin{array}{c}0.957 \\
(0.964) \\
\end{array}$ & \\
\hline PR & $\begin{array}{c}-0.291 \\
(-0.183)\end{array}$ & $\begin{array}{c}0.049 \\
(0.107)\end{array}$ & $\begin{array}{c}-0.045 \\
(-0.021)\end{array}$ & $\begin{array}{c}-0.268 \\
(-0.221)\end{array}$ & $\begin{array}{c}-0.050 \\
(-0.099)\end{array}$ & $\begin{array}{c}-0.223 \\
(-0.301)\end{array}$ & $\begin{array}{c}-0.291 \\
(-0.336)\end{array}$ & $\begin{array}{c}0.936 \\
(0.945)\end{array}$ \\
\hline
\end{tabular}

Perceived Asset Quality (PQ), Perceived Asset Price (PP), Facilitating Condition (FC), Performance Expectancy (PE), Perceived Asset Value (PV), Social Influence (SI), Investment Decision (ID), Perceived Financial Risk (PR).

In summary, all the above tests have confirmed all items are reliable and valid, which means it can be applied to evaluate the structural model.

\subsection{Structural Model}

Figure 2 shows PLS analysis results of the overall theoretical explanatory power of the model and estimated path coefficients. In Table 6, perceived asset quality and perceived asset price have a positive and significant effect on perceived asset value for both the South Korean and Chinese groups. Thus, H1 and $\mathrm{H} 2$ are supported. Then, perceived asset value, social influence and performance expectancy have a positive effect on investment decisions for both the South Korean and Chinese groups. Thus, H4, H6 and H7 are confirmed. Meanwhile, perceived financial risk's negative moderating effect between perceived asset value and investment decision is confirmed in the Chinese group but not in the South Korean group, whereas facilitating conditions' positive and significant effect on investment decision is confirmed in the South Korean group but not in the Chinese group. Overall, the two independent variables of perceived asset quality and perceived asset price have explained a large proportion of the variance $(16.2 \%)$ in perceived asset value in the Chinese group and $14.1 \%$ in South Korean group. Perceived asset value, facilitating conditions, social influence and performance expectancy have explained a large proportion of the variance $(24.4 \%)$ in investment decisions in the Chinese group and $20.4 \%$ in South Korean group. The Chinese group is in brackets and the South Korean group is outside the brackets. 


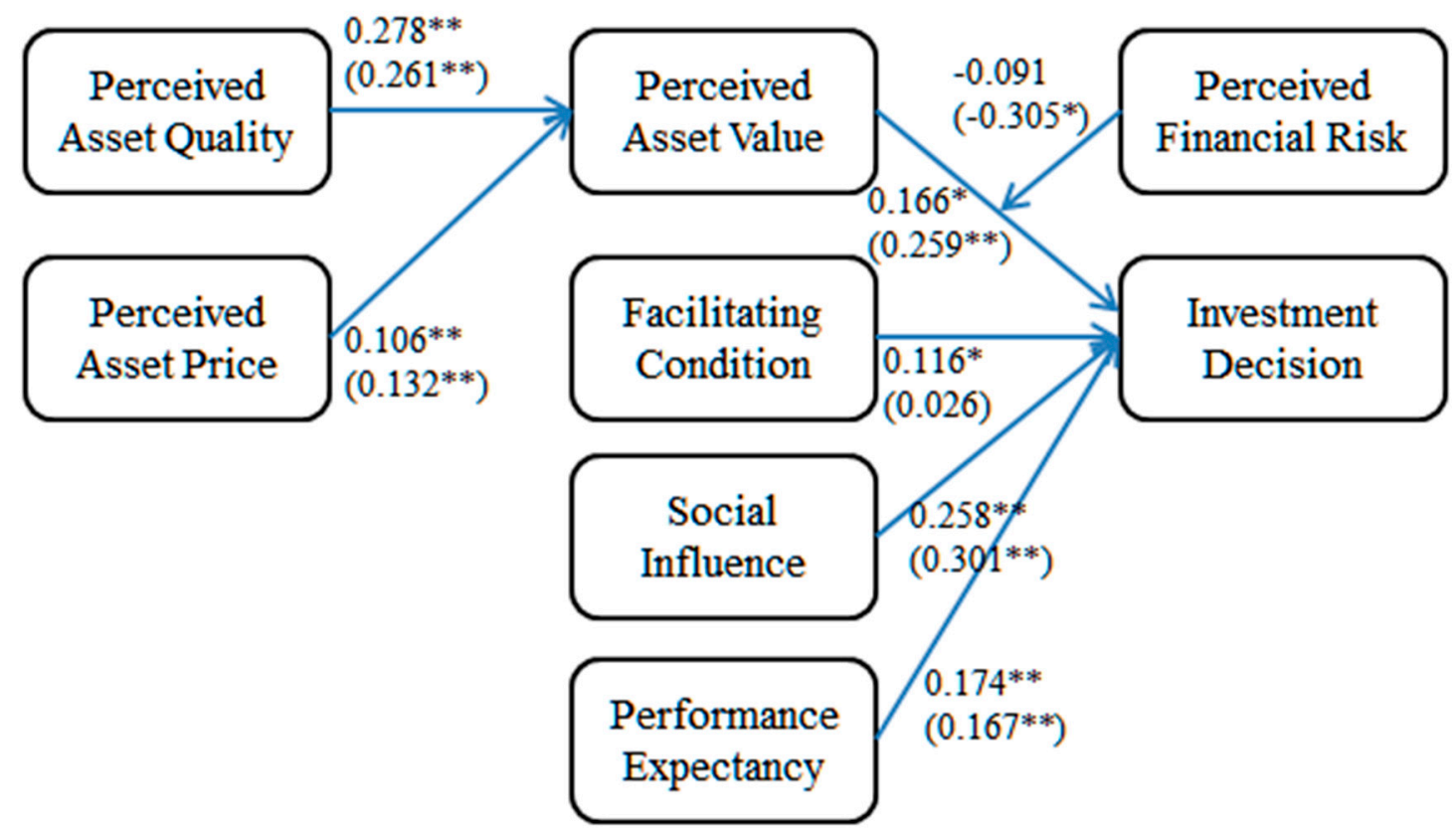

Figure 2. Structural model. Note: standardized coefficients ${ }^{*} p<0.05 ;{ }^{* *} p<0.01$.

Table 6. Results of hypotheses testing. Note: standardized coefficients ${ }^{*} p<0.05$; ${ }^{* *} p<0.01$.

\begin{tabular}{|c|c|c|c|c|}
\hline Hypotheses & Paths & Estimate & $t$-Value & Results \\
\hline H1 & $\begin{array}{c}\text { Perceived Asset } \\
\text { Quality } \rightarrow \text { Perceived Asset Value }\end{array}$ & $\begin{array}{c}0.278 \\
(0.261)\end{array}$ & $\begin{array}{c}12.488^{* *} \\
\left(13.531^{* *}\right)\end{array}$ & $\begin{array}{l}\text { Accepted } \\
\text { (Accepted) }\end{array}$ \\
\hline H2 & $\begin{array}{c}\text { Perceived Asset Price } \rightarrow \text { Perceived } \\
\text { Asset Value }\end{array}$ & $\begin{array}{c}0.106 \\
(0.132)\end{array}$ & $\begin{array}{l}5.030^{* *} \\
\left(5.321^{* *}\right)\end{array}$ & $\begin{array}{l}\text { Accepted } \\
\text { (Accepted) }\end{array}$ \\
\hline H3 & $\begin{array}{c}\text { Perceived Asset } \\
\text { Value } \rightarrow \text { Investment Decision }\end{array}$ & $\begin{array}{c}0.166 \\
(0.259)\end{array}$ & $\begin{array}{c}2.078 * \\
(2.849 * *)\end{array}$ & $\begin{array}{l}\text { Accepted } \\
\text { (Accepted) }\end{array}$ \\
\hline H4 & $\begin{array}{l}\text { Perceived Financial Risk's } \\
\text { Moderating Effect }\end{array}$ & $\begin{array}{l}-0.091 \\
(-0.305)\end{array}$ & $\begin{array}{c}1.207 \\
\left(2.294^{*}\right)\end{array}$ & $\begin{array}{l}\text { Not Accepted } \\
\text { (Accepted) }\end{array}$ \\
\hline H5 & $\begin{array}{c}\text { Facilitation } \\
\text { Conditions } \rightarrow \text { Investment Decision }\end{array}$ & $\begin{array}{c}0.116 \\
(0.026)\end{array}$ & $\begin{array}{l}2.378^{*} \\
(0.880)\end{array}$ & $\begin{array}{c}\text { Accepted } \\
\text { (Not Accepted) }\end{array}$ \\
\hline H6 & $\begin{array}{c}\text { Social Influence } \rightarrow \text { Investment } \\
\text { Decision }\end{array}$ & $\begin{array}{c}0.258 \\
(0.301)\end{array}$ & $\begin{array}{c}7.359 * * \\
(7.962 * *)\end{array}$ & $\begin{array}{l}\text { Accepted } \\
\text { (Accepted) }\end{array}$ \\
\hline H7 & $\begin{array}{c}\text { Performance } \\
\text { Expectancy } \rightarrow \text { Investment Decision }\end{array}$ & $\begin{array}{c}0.174 \\
(0.167)\end{array}$ & $\begin{array}{l}6.325^{* *} \\
\left(5.477^{* *}\right)\end{array}$ & $\begin{array}{l}\text { Accepted } \\
\text { (Accepted) }\end{array}$ \\
\hline
\end{tabular}

\section{Discussion}

Taking into consideration the importance of transnational institutional investors' behavior finance characteristics, this study focuses on how South Korean and Chinese institutional investors integrate certain types of assets of Cambodia into their investment to increase expecting returns. Especially, the study aimed to explore and compare the investment decision factors that lead South Korean and Chinese institutional investors to search for superior assets in Cambodian markets. Drawing on an extension of UTAUT theory, the research tries to propose a model for explaining the similarities and differences of investment decisions in Cambodian asset markets. Meanwhile, by contributing to the literature of comparative study and behavior finance research in the process of investment decision behavior, the research indicates that South Korean and Chinese institutional investors maintain symmetry in investment competition due to their different preferences in investment objects and types.

Empirical evidence of the study proves that the main drivers of investment decision for both groups are social influence, performance expectancy and perceived asset value, in order of impact. 
In addition, variables of perceived asset quality and perceived asset price affect the investment decision through the mediation variable of perceived asset value for both groups. Thus, the study partially confirms validity of the UTAUT theory about explaining investment decisions in the context of institutional investors for both groups.

Interestingly, together with the direct influence of perceived asset value, social influence and performance expectancy on investment decision for both groups, perceived financial risk proves to be a significant negative moderating factor on the relationship between perceived asset value and investment decision for the Chinese group but not for the South Korean group. This is probably because $61.1 \%$ of Chinese respondents (shown in Table 1) devoted themselves to investing real estate and entertainment, such as casinos, skyscrapers, villas, etc., which are typically high-risk and high-return investments. Due to the relatively low education level and less working experience in Cambodia compared with South Korean investors, it is not easy for them to manage corporate funding and liquidity associated with the profitable development and operation of an organization, which leads to a high sensitivity to perceived financial risk. For South Korean respondents, $47.5 \%$ of them focus on retail, financial industry and manufacturing, which can let their investments mature longer, allowing interest on savings to compound and reduce the financial risk.

However, facilitating conditions proves to be an important factor to investment decision for the South Korean group but not for the Chinese group. This may be due to $93.1 \%$ of South Korean respondents having a bachelor degree or above, whereas $42.9 \%$ of Chinese respondents only have a high school diploma. Furthermore, $61.5 \%$ of South Korean respondents have more than 3 years working experience in Cambodia, whereas $56.3 \%$ of Chinese respondents have less than 3 years working experience in Cambodia. Higher education level and longer working experience in Cambodia would help investors to find more possible facilitations to decrease costs in customs administration, human resource, transport and communications, etc., and increase their competitiveness. As well as this, compared with the South Korean group, there are more Chinese investors with greater financial power, which means they have strong financial strength to pursue their own acquisitions, such as building expressways, airports, ports and scenic areas. Because these projects are relatively new, it could be difficult for Chinese investors to find proper facilitations.

These findings could be useful in comparative research on Cambodia investment behavior. It contributes to the literature on transnational institutional investors' investment decisions in Cambodia, which little attention is given to by previous studies. Furthermore, this research can help to improve comparative research on transnational institutional investors' beliefs and attitudes toward investment decisions in Cambodia. Also, this study contributes much by introducing asset factors and moderating factors in the theoretical model, which play big roles as indirect and direct antecedents or moderating factors in the formation of investment decisions.

\section{Conclusions and Contributions}

One of the major findings of this research is the different influences of perceived financial risk and facility conditions on the decision behavior for Chinese and South Korean groups. Considering the outstanding rise of the Chinese economy, China is making its presence felt internationally, through buying, investing and influencing countries from Asia to Africa. Unfortunately, as it well-known, small- and mid-sized Chinese multinational firms lack overseas investment experience and global perspectives due to poor education; they cannot compete with developed countries such as South Korea in the high-tech fields. Thus, people suspicious of China's overseas expansion may find that Chinese overseas investment cannot influence other developing countries' economic policy or national security in the long run. As a matter of fact, the technological innovation of developed countries is always the key to national competitive advantage and to China. If we look at the strengths of developed countries, they still look relatively strong compared to the challenges China faces, because what decides a country's competitive or comparative advantage lies more on knowledge, innovation and universal values. 
This study contributes to the current research in several perspectives. Firstly, there is little existing research focusing on the comparative study between China and developed countries' investment behavior in overseas investment. Secondly, SEM (Structural Equation Model) is applied to investigate how multinational investors' behaviors affect their investment decisions. Thirdly, Cambodia, as one of the least-developed countries, has been ignored for a long time in the investment research field, so that it is high time to carry on related research contributing to the development of Cambodia. Additionally, the results indicate that different countries can have different competitive advantages in the same overseas investment process, because they can maintain symmetry in investment competition due to their different knowledge, skills, policies, comparative advantages and preferences. Therefore, this study expands the breadth and depth of overseas investment study from pure competition to win-win cooperation and opens up new areas of competitive and comparative research between developing and developed countries in a symmetrical perspective.

\section{Managerial Implications}

Results of this study suggest implications for the financial and marketing strategies in Cambodia investment. Knowledge of transnational institutional investors' investment decisions and in particular the role of asset view and financial risk are useful for future management strategies in encouraging transnational institutional investors to invest. Therefore, both the transnational investment corporations and the Cambodian government will be able to explore their financing and taxation policies, and regulatory, advertisement, websites or risk management's effects, and attempt to find proper policies to attract more transnational institution investors.

It is also necessary to enhance asset characters to especially look for undervalued assets in Cambodia, such as jewelries, real estate, agricultural lands and products, company stocks and financial licenses. In this sense, the government could also pay more attention to classifying different kinds of assets to form trading platforms with local characteristics in order to offer more facilitating conditions for foreign investors to help them find what they need. Because financial investment marketing in Cambodia remains in an imitation stage and does not form a service system, it is useful to establish an official and trustworthy information-sharing platform similar to Bloomberg to help institutional investors share information, engage in over-the-counter trading and increase influence among each other. Moreover, if the financial market entry threshold could be lowered and management of investment quotas could be given less control, investors' creativity will be enhanced and performance expectancy will be increased.

Notably, perceived financial risk plays an important negative moderating role between the relationship of perceived asset value and investment decision. It can be reduced through government credit guarantee, strict legal protection and other related stricter laws. Furthermore, an online approval system should be applied in order to adapt to the administrative examination and approval system, improve the efficiency of government offices, optimize the approval process, and to streamline government agencies to better serve the institution investment by offering appropriate regulations according to different investment preferences of different institutional investors.

\section{Limitations and Future Research}

This research had encountered some limitations which need to be taken into account. First, this study is classified as cross-sectional study, which means data was gathered at a single fixed period of time to study the relationship between independent variables and dependent variables. However, the independent variables that influence investment decision may change over time. Therefore, the result only can indicate the current situation and may not be representative in the future. Moreover, this research is merely conducted in South Korean and Chinese investors in Cambodia. This may lead to a difference in the results acquired if the same research model was used in other countries with different social behaviors and cultural backgrounds. Therefore, the consistency of the research result in different countries context has to be verified in future studies. Thus, it is suggested that future 
studies should consider collecting larger samples of international investors in Cambodia. Moreover, by focusing on asset dimensions and financial risk, this study only considered the protective factors and motivational forces that mainly lie within the institutional investors. Furthermore, research on what influence categories of assets of Cambodia in the investors' portfolio is highly needed, and what factors determine investors' long-term or short-term investment strategies should be also considered in future research.

Author Contributions: W.S. contributions include concepts, study design, statistical analysis and manuscript editing. A.T.D. contributions include literature research, study design and manuscript definition of variables' content. H.Y.S. contributions include data acquisition, analysis, interpretation and statistical analysis. K.S.K. contributions include study concepts, data acquisition \& analysis and manuscript preparation.

Funding: This research received no external funding.

Conflicts of Interest: We declare no conflict of interest.

\section{References}

1. Shim, G.Y.; Lee, S.H.; Kim, Y.M. How investor behavioral factors influence investment satisfaction, trust in Investment Company, and reinvestment intention. J. Bus. Res. 2008, 61, 47-55. [CrossRef]

2. Chen, C.J.; Lin, Y.H. Managing the foreign investment portfolio: How industry and governance diversity influence firm performance. Int. Bus. Rev. 2016, 25, 1235-1245. [CrossRef]

3. Knill, A.M. Does Foreign Portfolio Investment Reach Small Listed Firms? Eur. Financ. Manag. 2010, 19, 251-303. [CrossRef]

4. Cumming, D.; Haß, L.H.; Schweizer, D. Strategic Asset Allocation and the Role of Alternative Investments. Eur. Financ. Manag. 2014, 3, 20-547. [CrossRef]

5. Sa-Aadu, J.; Shilling, J.; Tiwari, A. On the Portfolio Properties of Real Estate in Good Times and Bad Times. Real Estate Econ. 2010, 38, 529-565. [CrossRef]

6. Anglin, P.M.; Gao, Y. Integrating Illiquid Assets into the Portfolio Decision Process. Real Estate Econ. 2011, 39, 277-311. [CrossRef]

7. Btartram Sohnke, M. Gunter Dufey. International Portfolio Investment: Theory, Evidence, and Institutional Framework. Financial Markets. Inst. Instrum. 2001, 10, 85-155. [CrossRef]

8. $\mathrm{Wu}, \mathrm{J}$; $\mathrm{Ma}, \mathrm{Z}$.; Liu, Z. The moderated mediating effect of international diversification, technological capability, and market orientation on emerging market firms' new product performance. J. Bus. Res. 2019, 99, 524-533. [CrossRef]

9. Verbeke, A.; Liena, K. An internalization theory perspective on the global and regional strategies of multinational enterprises. J. World Bus. 2016, 51, 83-92. [CrossRef]

10. Hitt, M.; Dan, L.; Kai, Xu. International strategy: From local to global and beyond. J. World Bus. 2016, 51, 58-73. [CrossRef]

11. Casson, M.; Nigel, W. Emerging market multinationals and internalization theory. Int. Bus. Rev. 2018, 27, 1150-1160. [CrossRef]

12. $\mathrm{Wu}, \mathrm{J} . ; \mathrm{Ma}, \mathrm{Z}$; Zhou, S. Enhancing national innovative capacity: The impact of high-tech international trade and inward foreign direct investment. Int. Bus. Rev. 2017, 26, 502-514. [CrossRef]

13. Chen, K.Y.; Elder, R.J.; Hung, S. The Investment Opportunity Set and Earnings Management: Evidence from the Role of Controlling Shareholders. Corp. Gov. 2012, 18, 193-211. [CrossRef]

14. Brandon, J.; Yook, Y. Political Uncertainty and Corporate Investment Cycles. J. Financ. 2012, 67, 45-83.

15. Walter, I.; Sisli, E. The Asset Management Industry in Asia: Dynamics of Growth, Structure, and Performance. Financ. Mark. Inst. Instrum. 2007, 16, 1-77. [CrossRef]

16. Sokang, K. The Impact of Foreign Direct Investment on the Economic Growth in Cambodia: Empirical Evidence. Int. J. Innov. Econ. Dev. 2018, 4, 31-38. [CrossRef]

17. Wittwer, A.; Nasdala, L.; Wanthanachaisaeng, B.; Bunnag, N.; Škoda, R.; Balmer, W.A.; Giester, G.; Zeug, M. Mineralogical characterisation of gem zircon from Ratanakiri, Cambodia. In Proceedings of the Conference on Raman and Luminescence Spectroscopy in the Earth Sciences, Vienna, Austria, 3 July 2013.

18. Zeug, M.; Nasdala, L.; Wanthanachaisaeng, B.; Balmer, W.A.; Corfu, F.; Wildner, M. Blue Zircon from Ratanakiri Cambodia. J. Gemmol. 2018, 36, 112-132. [CrossRef] 
19. Aiba, D.; Ken, O.; Vouthy, K. Foreign currency borrowing and risk-hedging behavior: Evidence from Cambodian households. J. Asian Econ. 2018, 58, 19-35. [CrossRef]

20. Samreth, S. An empirical study on the hysteresis of currency substitution in Cambodia. J. Asian Econ. 2011, 22, 518-527. [CrossRef]

21. Venkatesh, V.; Morris, M.G.; Davis, G.B.; Davis, F.D. User acceptance of information technology: Toward a unified view. MIS Q. 2003, 27, 278-425. [CrossRef]

22. Dwivedi, Y.K.; Shareef, M.; Simintiras, A.C.; Lal, B.; Weerakkody, V. A generalised adoption model for services: A cross-country comparison of mobile health (m-health). Gov. Inf. Q. 2016, 33, 174-187. [CrossRef]

23. Shaw, N.; Ksenia, S. The non-monetary benefits of mobile commerce: Extending UTAUT2 with perceived value. Int. J. Inf. Manag. 2019, 45, 44-55. [CrossRef]

24. Chang, H.H.; Wong, K.H.; Li, S.Y. Applying push-pull-mooring to investigate channel switching behaviors: M-shopping self-efficacy and switching costs as moderators. Electron. Commer. Res. Appl. 2017, 24, $50-67$. [CrossRef]

25. Jiang, L.; Jun, M.; Yang, Z. Customer-perceived value and loyalty: How do key service quality dimensions matter in the context of B2C e-commerce? Serv. Bus. 2016, 10, 301-317. [CrossRef]

26. Kuo, Y.-F.; Wu, C.-M.; Deng, W.-J. The relationships among service quality, perceived value, customer satisfaction, and post-purchase intention in mobile value-added services. Comput. Hum. Behav. 2009, 25, 887-896. [CrossRef]

27. Goode, S.; Lin, C.; Tsai, J.C.; Jiang, J.J. Rethinking the role of security in client satisfaction with Software-as-a-Service (SaaS) providers. Decis. Support Syst. 2015, 70, 73-85. [CrossRef]

28. Lu, Y.; Zhang, L.; Wang, B. A multidimensional and hierarchical model of mobile service quality. Electron. Commer. Res. Appl. 2009, 8, 228-240. [CrossRef]

29. Fang, J.; Wen, C.; George, B.; Prybutok, V.R. Consumer heterogeneity, perceived value, and repurchase decision-making in online shopping: The role of gender, age, and shopping motives. J. Electron. Commer. Res. 2016, 17, 116.

30. Cocosila, M.; Trabelsi, H. An integrated value-risk investigation of contactless mobile payments adoption. Electron. Commer. Res. Appl. 2016, 20, 159-170. [CrossRef]

31. Hsu, C.L.; Lin, J.C.C. What drives purchase intention for paid mobile apps?-An expectation confirmation model with perceived value. J. Electron. Commer. Res. Appl. 2015, 14, 46-57. [CrossRef]

32. Dowling, G.R.; Staelin, R. A model of perceived risk and intended risk-handling activity. J. Consum. Res. 1994, 21, 119-134. [CrossRef]

33. Forsythe, S.; Liu, C.; Shannon, D.; Gardner, L.C. Development of a scale to measure the perceived benefits and risks of online shopping. J. Interact. Mark. 2006, 20, 55-75. [CrossRef]

34. Lim, N. Consumers' perceived risk: Sources versus consequences. Electron. Commer. Res. Appl. 2003, 2, 216-228. [CrossRef]

35. Chen, Z.; Dubinsky, AJ. A conceptual model of perceived customer value in E-commerce: A preliminary investigation. Psychol. Mark. 2003, 20, 323-347. [CrossRef]

36. Forsythe, S.M.; Shi, B. Consumer patronage and risk perceptions in Internet shopping. J. Bus. Res. 2003, 56, 867-875. [CrossRef]

37. Chang, E.C.; Tseng, Y.F. Research note: E-store image, perceived value and perceived risk. J. Bus. Res. 2013, 66, 864-870. [CrossRef]

38. Bhatnagar, A.; Ghose, S. Segmenting consumers based on the benefits and risks of internet shopping. J. Bus. Res. 2004, 57, 1352-1360. [CrossRef]

39. Venkatesh, V.; Thong, J.; Xu, X. Consumer acceptance and use of information technology: Extending the unified theory of acceptance and use of technology. MIS Q. 2012, 36, 157-178. [CrossRef]

40. Hossain, M.A.; Hasan, M.I.; Chan, C.; Ahmed, J.U. Predicting user acceptance and continuance behavior towards location-based services: The moderating effect of facilitating conditions on behavioral intention and actual use. Australas. J. Inf. Syst. 2017, 21. [CrossRef]

41. Oliveira, T.; Thomas, M.; Baptista, G.; Campos, F. Mobile payment: Understanding the determinants of customer adoption and intention to recommend the technology. Comput. Hum. Behav. 2016, 61, 404-414. [CrossRef]

42. Patnasingam, P.; Gefen, D.; Pavlou, P.A. The role of facilitating conditions and institutional trust in electronic marketplaces. J. Electron. Commer. Organ. (JECO) 2005, 3, 69-82. [CrossRef] 
43. Gonzalez, F. Bank Equity Investments: Reducing Agency Costs or Buying Undervalued Firms? The Information Effects. J. Bus. Financ. Account. 2006, 33, 284-304. [CrossRef]

44. Sun, J. How risky are services? An empirical investigation on the antecedents and consequences of perceived risk for hotel service. Int. J. Hosp. Manag. 2014, 37, 171-179. [CrossRef]

45. Tsao, W.C.; Chang, H.R. Exploring the impact of personality traits on online shopping behavior. Afr. J. Bus. Manag. 2010, 4, 1800-1812.

46. Hair, J.F.; Ringle, C.M.; Sarstedt, M. PLS-SEM: Indeed a silver bullet. J. Mark. Theory Pract. 2011, 19, $139-151$. [CrossRef]

47. Henseler, J.; Ringle, C.M.; Sinkovics, R.R. The use of partial least squares path modeling in international marketing. Adv. Int. Mark. 2009, 20, 277-319.

48. Bagozzi, R.; Yi, Y. On the evaluation of structural equation models. J. Acad. Mark. Sci. 1988, 16, 74-94. [CrossRef]

49. Fornell, C.; Bookstein, F.L. Two structural equation models: LISREL and PLS applied to consumer exit-voice theory. J. Mark. Res. 1982, 19, 440-452. [CrossRef]

50. Gefen, D.; Straub, D. A practical guide to factorial validity using PLS-Graph: Tutorial and annotated example. Commun. Assoc. Inf. Syst. 2005, 16, 5. [CrossRef]

(C) 2019 by the authors. Licensee MDPI, Basel, Switzerland. This article is an open access article distributed under the terms and conditions of the Creative Commons Attribution (CC BY) license (http://creativecommons.org/licenses/by/4.0/). 